\title{
Lucia Morra
}

lucia.morra@unito.it

\section{Sraffa, Hume, and Wittgenstein's Lectures On Belief}

\section{Abstract}

As the recent edition of the Wittgenstein's Whewell's Court Lectures shows, Wittgenstein mentioned Hume several times in the series of lectures on belief. Towards the end of the Thirties, in fact, he came across Hume's Abstract of the Treatise, a pamphlet that Piero Sraffa and John Maynard Keynes had 'discovered' at the end of 1933, re-edited in 1937 and finally published in March 1938 - Sraffa donated him a copy. Excerpts of Wittgenstein's ET 1940 lectures strongly suggest that he read the Abstract in March-May 1940, and show that some of the issues he discussed in his lectures at that time revolve around the peculiar definition that Hume gave in that text of the feeling of belief.

\section{A Peculiarity and a Hypothesis}

Streams of Wittgenstein's research can be depicted as tangential to Humean fields of enquiry, and some of the arguments he developed can be interpreted as a refutation of Hume's perspective; yet, he never mentioned the Scottish philosopher in his writings. Nothing out of the ordinary, given his disregard for philological issues; quite the opposite, it is remarkable that in the second half of the Thirties he actually mentioned Hume to his students. As far as is known, he had never done it before, nor did he later.

Wittgenstein made his first direct reference to the author of the Treatise of Human Nature in a lecture of May 1936 (\$4.1). Being one- 
shot, the reference did not arouse scholarly attention, whereas mentions of Hume in his March-May 1940 lectures were frequent (\$\$4.2, 4.3), and the editors of the Whewell's Court Lectures (hereinafter: WCL) paired them with excerpts of the Treatise and also, lacking any evidence that Wittgenstein ever read it, with quotations of Hume in William James' Principles of Psychology (WCL: 204 , n.8; 174, n.71), a text he reportedly referred to in his lectures of that time, and in Bertrand Russell's Theory of Knowledge, a manuscript upon which Wittgenstein had severely commented in 1913 (WCL: 204, n.8). Another plausible source is Russell's Analysis of Mind, a relevant text for Wittgenstein throughout the Thirties, but a further possibility is suggested also by the very timing of Wittgenstein's most frequent 'quotations' of Hume (Spring 1940) when considered on the background of his conversations with the economist Piero Sraffa, most frequent in 1938-1941 (\$3); ${ }^{1}$ namely, that towards the end of the Thirties he came across Hume's Abstract of the Treatise, a pamphlet that Sraffa and Keynes had 'discovered' at the end of 1933, re-edited in 1937 and finally published in March 1938 - Sraffa, indeed, gave him a copy (\$2). ${ }^{2}$ As shown in $\$ 4$, several excerpts of the Lectures on Belief suggest in fact that Wittgenstein read the Abstract, a circumstance that may throw further light on the paths followed by his reflection towards the end of the Thirties (\$5).

\section{Sraffa's and Keynes' 1938 edition of Hume's Abstract}

John Maynard Keynes and Piero Sraffa, two of Wittgenstein's close friends, shared a passion for antiquarian books. Towards the end of 1933, Keynes came into possession of one of the rare extant copies of a pamphlet anonymously published in 1740, An Abstract of a

\footnotetext{
${ }^{1}$ In 1938-1941 Sraffa and Wittgenstein met more frequently than in 1930-1933, namely 115 times plus the meetings unrecorded in their diaries: unless further specified, data about their intercourse here reported are taken from Morra (2017: 107-113; 123-129).

${ }^{2}$ A copy of the Abstract with an (undated) dedication of Sraffa to Wittgenstein was sold in June 2004 by Dominic Winter Auctioneers as part of a set of items belonged to Rush Rhees (lot 336). A photograph of the inscription in Sraffa's hand - "To Ludwig Wittgenstein Piero Sraffa" - is printed in the auction catalogue. Rhees probably came into possession of the book after Wittgenstein's death. Examined with the kind permission of its present owner, the book looks like having been read, but has no annotations.
} 
Book lately Published: entituled a Treatise of Human Nature, \&o. wherein the Chief Argument of that Book is farther illustrated and explained Keynes "held [Hume] in high esteem" (Barens 2011: 29), and collected his works "for almost as long as he collected books" (Johnson and Moggridge: 373).

Shortly after the pamphlet arrived in Keynes' hands, Sraffa carefully examined it, and concluded that it might not be an early work of Adam Smith as held in the received view. Before leaving Cambridge for Christmas vacation, he put forth his doubts to Keynes, who then wrote him:

I have now read the Hume pamphlet carefully and lean strongly to your view that it is by Hume himself. Literally there is nothing inconsistent with this, whilst the Adam Smith story looks very unlikely. (JMK to PS 5.1.1934) ${ }^{3}$

Doubts were confirmed by a keen examination of Hume's correspondence and texts. The joint introduction to the facsimile reprint of the Abstract they published four years later not only debunked the hypothesis of Adam Smith's authorship, but advanced strong evidence that Hume himself had written the pamphlet, possibly to raise interest for his 'stillborn' $A$ Treatise of Human Nature. Scholars had been misled in the first place by Hume's reference in a letter to Hutcheson to an unspecified "Mr. Smith" to whom he (Hume) acknowledges to have sent a copy of the pamphlet shortly after its publication and second, by Hutcheson's habit of giving his most brilliant students the task of compiling compendia of the books that were read - Adam Smith, 17 at that time, was indeed one of his most gifted pupils. Sraffa and Keynes pointed out however that Hume's sending "Mr. Smith" a copy of the pamphlet was in this hypothesis an incongruous fact, and proposed that the reference was rather to John Smith, the Irish publisher of Hutcheson's books; Hume was exploring the possibility of a second edition of his Treatise to amend some parts of it, which could be done in Ireland without breaching the contract with the London publisher, so Hutcheson could well have suggested him Smith's name.

${ }^{3}$ Sraffa's Papers D3/11/65: 61. 
As regards the authorship of the pamphlet, Keynes and Sraffa put forth convincing reasons for arguing that Hume himself wrote it. ${ }^{4}$ Not only two excerpts of the Abstract anticipate themes Hume will later discuss in the Philosophical Essays concerning Human Understanding (Keynes, Sraffa 1938: xxix). Above all, the comparison between the Abstract and the Appendix to Vol III of the Treatise shows that its "contents could not have been contributed by anyone but Hume himself, since they involve an anticipation of Hume's additions to the Treatise which were not published until subsequently" (ibid: xxiv). The first two volumes of the Treatise were published in January 1739; shortly afterwards several amendments came to Hume's mind, and in November 1740 Book III was published with an Appendix Wherein some Passages of the foregoing Volumes are illustrated and explained. The Appendix concerns in fact only Book I, and it is divided in two parts: the first discussing the nature of belief and advancing additions to be inserted in Parts III and IV, the second tackling the section on personal identity (also in Part IV of Book I) and acknowledging a few minor errors in Parts I and II. The partition of the Appendix mirrors the chronological order in which Hume conceived the amendments to Book I: additions to be inserted in Parts III-IV first, and then corrections to Parts I-II (ibid: xxiv-xxv). Printed not later than March 1740, the Abstract too focuses on Book I of the Treatise - Hume thought it the most appealing part of his work, and neglected Book II apart from a paragraph devoted to the treatment of freedom of the will (Hume 1938: 28-31). The pamphlet anticipating "several points discussed in the first part of Appendix, but none of those, and particularly not the corrections, in the second part" matches with the fact that it had been published seven months before the Appendix (Keynes, Sraffa 1938: xxv).

Keynes and Sraffa possibly caressed the idea of reprinting the Abstract already in 1934, but the editorial project started only after Keynes published the General Theory, and was further delayed by several illnesses which afflicted Keynes from January 1937, preluding to a collapse in May (Skidelsky 2000: 3-14). In early

${ }^{4}$ A claim later proved by the finding of a copy of the Abstract with textual emendations in Hume's own handwriting (Gehrke 2010: 4). 
September, however, from Tilton where he was to convalesce for several months, Keynes communicated to Sraffa his wish to finish off in the autumn the Hume Abstract "as a piece of light work" (JMK to PS 5.9.1937, Add.ms.a 427/41). A month later, Sraffa sent him his draft, that included the section proving Hume's authorship through a comparison of his texts, and Keynes completed corrections and additions for the whole Introduction by the end of November. ${ }^{5}$ Sraffa received the first proof in Italy, merged his own corrections with those of Keynes when he was back in Cambridge, and sent the final version to the Press on January the $26^{\text {th }}{ }^{6}$ The book was published not later than March 21.

\section{Sraffa, Wittgenstein and the Abstract}

When Sraffa read the Abstract for the first time, at the end of 1933, he and Wittgenstein had just resumed the conversations they used to have during terms since MT 1930. That term, in fact, their

\footnotetext{
${ }^{5}$ Keynes scholars used to sketch out a secondary character for Sraffa both in the discovery of Hume's authorship and in the Introduction to the Abstract (i.e., Johnson and Moggridge 1978: 373; Harrods 1951: 483; Skidelsky 2000: 12), but further research assessed his primary role in both, and also that he was the sole author of section IV performing the 'internal analysis of coherence of the hypothesis' of Hume's authorship, an evidence corroborated by the reprint in Keynes Collected Writings of only the first three sections of the Introduction (Keynes 1978). Sraffa's Papers contain neither the copies of his drafts nor of those of Keynes, but the respective authorship is witnessed by their correspondence - see PS to JMK, 13.10 .1937 (King's/PP/JMK/PP/64/4-5, 6-7), JMK to PS 18.10.1937 (Add.ms.a 427/44); PS to JMK 20.10.1937 (King's/PP/JMK/PP/64/89); JMK to PS 28.10.1937 (Add.ms.a 427/46); JMK to PS 1.11.1937, King's/PP/JMK/PP/64/27-28); JMK to PS 14.11 .1937 and 27.11.1937 (King's/PP/64/29-37; 46-54). See also Keynes' letters in which he attributed to Sraffa the intuitions of Hume's authorship and Smith's non-authorship, namely JMK to PS 5.1.1934 (already quoted), JMK to Rudolf Metz 5.10.1938 (Sraffa C 155: 4), and finally a letter Maynard wrote in 1940 to secure Sraffa's release from the internment camp (K: UA/5/5/183-4, in Gehrke 2010: 3, n. 5).

${ }^{6}$ PS to JMK 4.12.1937, JMK to PS 6.12.1937, PS to JMK 7.12.1937 and 15.12.1937 (King's/PP/JMK/PP/64/58-68; 80-81); JMK to PS 29.12.1937 and 13.1.1938 (King's/PP/JMK/PP/64/92; 98); PS to JMK 21.1.1938, JMK to PS 22.1.1938, and PS to JMK 26.1.1938 (King's/PP/JMK/PP/64/103-111).

${ }_{7}^{7}$ Cf. what Norman Kemp Smith wrote to Keynes on March 21 (NKS to JMK 21.3.1938, Sraffa C155/38). The book was out probably before March 17; Keynes was in Cambridge the weekend 10-14 March for the Fellowship Elections, his first visit since late Spring 1937 (Skidelski 2000: 14); Sraffa left on March 18/19 to Italy.
} 
weekly practice had started later than usual; their first scheduled meeting was only at the end of November, and the delay was due not only to their respective engagements in the first part of term. As Wittgenstein was later to recall, towards the end of May he had perceived their conversations as nervous and tiresome (LW to PS 19.1.1934), ${ }^{8}$ and he was to perceive as such also the conversations they had from November 25, since on the eve of Sraffa's departure to Italy in mid-December he told him that he wished to schedule no conversation for the following term (ivi).

At any rate, the timing of their meetings before Christmas vacation coincides with the period in which Sraffa read the Abstract and conceived his suspicions about its real author (\$2), so it is possible that Wittgenstein was informed of these suspicions; in the unlikely hypothesis that he proved indifferent to the possible existence of an 'hitherto unknown' book of Hume, the 'mystery' of the pamphlet certainly suited his taste in detective stories - in fact, the combination of the 'external' and 'internal' lines of research that led to its solution ${ }^{9}$ is worth one of Agatha Christie's books, that he reportedly used to enjoy very much at that time (Drury 1981b: 147).

Wittgenstein held firm to his resolution to cut off regular meetings with Sraffa only until the end of January (a month in which Sraffa commented with Keynes upon the issues posed by the pamphlet); ${ }^{10}$ since then, they tried to meet on weekends and exchanged notes in between (see \5). In the next term, though, they met only twice for a discussion, in MT 1934 fixed no conversations, and arranged just a couple of them in LT 1935; weekly conversations were resumed in Spring 1935, but stopped already in November. The re-printing of the pamphlet was settled while Wittgenstein was in Norway - his research fellowship having expired, he had decided to retire there to work - but while in

\footnotetext{
${ }^{8}$ Unless otherwise specified, Wittgenstein's letters here quoted are published in WC.

${ }^{9}$ The 'external line of research' led to the Irish editor as the reference of Hume in the letter to Hutcheson, whereas the 'internal line of research' was the textual comparison in favour of Hume's authorship.

${ }^{10}$ A letter Keynes wrote on 16.2.1934 tells us that by then he and Sraffa had already in mind the lines along which they were to prove both Adam Smith's non-authorship and Hume's authorship (K: RES/1/2/19).
} 
Cambridge for vacations, he was possibly informed about the advancements of the editorial project. ${ }^{11}$ When he was again in Cambridge in January 1938, he met Sraffa twice while the latter was revising the final proof of the pamphlet - and met him three more times before going to Ireland where he planned to stay. As is known, the Anschluss pressed him to return to Cambridge in order to discuss with Sraffa the best course of action for him to take, so they met on March 17; by which time the Abstract had probably been published ( $\$ 2)$, so Sraffa might have donated Wittgenstein his copy already on that occasion. Though, given the urgent matters they had to discuss, it is likely that the gift was postponed after vacations; Sraffa, who was to leave the next day for Italy, had also planned to go to Vienna and offered to act as a go-between for Wittgenstein and his family, a move that convinced the philosopher to give up his plan to go there as still an Austrian citizen (LW to PS 30.3.1938, 1.4.1938).

Since Sraffa was back in England and until June 1941 a new intense period of their intellectual intercourse began, in which they discussed even more frequently than in 1930-1933 - furthermore, they were both Trinity men from October 1939. Conversations with Sraffa run regularly not only as long as Wittgenstein held both the WCL (ET 1938, MT 1939, LT 1940, ET 1941) and the lectures on the foundations of mathematics (LT 1939, ET 1939), but even when he did not teach, as in MT 1938. True, at the beginning of 1940 they had a severe quarrel (LW to PS, [3.1.1940]) later remembered by Wittgenstein as a breaking point in their relationship (LW to PS 10.10.1947), but already in February they were meeting frequently again.

In this intense period of their friendship Sraffa might have given Wittgenstein his copy of Hume's Abstract any time; when this happened cannot be ascertained, but what really matters is if and when Wittgenstein read it, a question to which, as the next section

\footnotetext{
${ }^{11}$ On January 15, Wittgenstein met Sraffa in the morning and Keynes in the afternoon (cf. Sraffa's and Wittgenstein's diaries with LW to PS [14.1.1937] and 16.1.1937). Three days later, Keynes wrote Sraffa the first letter in their correspondence about the publication (JMK to PS 18.1.1937, K: UA/14/2/245-6). Wittgenstein met Sraffa (not Keynes, at that time in Wales) several times also in June-July.
} 
shows, a textual analysis of his allusions to Hume gives a tentative answer - in fact, some passages of the WCL strongly suggest that he read it within April 1940.

\section{A Textual Analysis of Wittgenstein's References to Hume in 1936-1940}

As was said ( $(\mathbb{1})$, as far as is known, Wittgenstein mentioned Hume once in a lecture of 1936 and several other times in the lectures of Spring 1940. In order to evaluate whether in any of these occasions he could have had Hume's Abstract in mind, the present section investigates whether textual evidence of such a reading can be found in any of Wittgenstein's mentions of Hume that his students reported; tentative hypothesis about the place this reading may have had in his reflections are sketched out in the next section ( $(5)$.

\subsection{Easter Term 1936 - Lectures on The Language of Sense Data and Private Experience}

According to Rush Rhees' notes, Wittgenstein mentioned Hume the first time in the lecture of May 13, 1936. While talking about memory, he reportedly said:

We can use the word "past" where nothing has "passed". This is not a peculiarity of memory. We also use the words "clearly" and "unclearly" - which have been used in such and such a fashion - and speak of remembering clearly or unclearly. This is a peculiar character of memory.

Remember Hume's description of "ideas" as "faint copies". If he had said "When I drink beer I see things fainter", he would have described an experience. Whereas he didn't. (RSD: 344)

Hume, though, described ideas as faint copies in none of his texts. He defined them as faint perceptions/images, and also, more in the Essays than in the Treatise and remarkably not in the Abstract, as copies of 
perceptions, without further adjectives. ${ }^{12}$ While the first definition was pivotal in his perspective, the second focussed on an aspect that he considered secondary although entailed by the derivation of ideas from perceptions, and that he left opaque - hence the absence of adjectives further qualifying the concept of copies of perceptions in his writings. At any rate, being the reference of the expressions faint perceptions and copies of perceptions the same for him, adding the adjective faint to the second would have been redundant if not confusing.

The words Wittgenstein used to express Hume's claim exclude then a direct quotation of any of Hume's texts. The mention being part of a remark concerning the peculiarity that Russell had recognised as essential to memory in The Analysis of Mind suggests a search in this text, even if Russell described ideas as more or less accurate/imperfect/vague copies (i.e., Russell 1921: 160, Russell 1927: 199-200), never as faint copies. ${ }^{13}$ In fact, in the pages closing the section devoted to sensations and images, just before the section on memory, Hume's statement "by ideas I mean the faint images of [impressions]" is quoted twice (Russell 1921: 146, 155), and shortly after in the text not only Russell sketched out the peculiarity of memory under Wittgenstein's scrutiny at that moment of the lecture, but zoomed on the trait of ideas left opaque by Hume their being copies of sensations (Russell 1921: 157-159). Wittgenstein's misreport of Hume's claim was then possibly due to

\footnotetext{
${ }^{12}$ Sometimes Hume used images instead of perceptions, i.e. T I.I.I. (Hume 1978: 1); weak/feeble instead of faint, representations instead of copies; and finally impressions instead of perceptions. In Essays II and VII, he defined ideas as copies while expanding his critique to Locke's denial of the theory of innate ideas - i.e., "no more was meant by those, who deny'd innate ideas, than that all our ideas were copies of our impressions" (Hume 1975: 22, see also 19); "all our ideas are nothing but copies of our impressions" (ibid.: 62). In the Treatise, he defined ideas as copies twice - "all ideas [...] are nothing but copies and representations of [impressions]", and "contradiction consists in the disagreement of ideas, consider'd as copies, with those objects, which they represent", respectively $\mathrm{T}$ I.I.VII and T II.III.III (Hume 1978: 19, 415). In the Appendix, he did not define ideas as copies, but he wrote in the advertisement to Book III of the Treatise: "by ideas [I mean] the copies of [perceptions] in the memory and imagination" (Hume 1978: 454).

${ }^{13}$ The same holds for James' The Principles of Psychology (1890) and Psychology: Briefer Course (1892), both quoting Hume and in which James, as Russell did later, thought that Hume's conception of ideas left no room for their vagueness, see, for instance, James (1890: 691) and (1892: 147).
} 
a superposition of the focus that Russell put onto ideas as copies; of the original statement he retained the adjective faint possibly because a few pages before Russell had insisted on the faint character of images when arguing that the criterion set up by Hume for distinguishing ideas (images in his perspective) from perceptions (sensations in his words), namely their "less degree of vividness", was not "universally applicable" (Russell 1921: 145). ${ }^{14}$

\subsection{Lent Term 1940 - Lectures On Description}

According to Smythies' notes, Wittgenstein mentioned Hume once again four years later, namely towards the end of Lent Term 1940, in lecture eight of the series On Description (WCL: 137-199): ${ }^{15}$

Cf. Hume's remarks that images are lacking in the vivacity and liveliness of perceptions. If you say they are lacking in vivacity, this suggests you could tell a man what an image is by: 'It's like a perception, but lacking in vivacity'. I might say: 'Well, what kind of vivacity is it lacking in?' This is an intolerably misleading idea. It would come to something like saying: 'If they only had more vivacity, they'd be perceptions.' (WCL: 174, < March $4>1940)^{16}$

An editorial note (WCL: 174, n.71) detects parallels amongst the first sentence and three passages of the Treatise, namely T I.I.VII (Hume 1978: 19, quoted in James 1890: 692), ${ }^{17}$ T I.III.V (Hume 1978: 85), and T III.I.Adv. (ibid.: 454). Here again Wittgenstein's

\footnotetext{
${ }^{14} \mathrm{I}$ 'm indebted to one of the anonymous reviewers for suggesting this line of research.

${ }_{15}$ Titles of the WCL - with the exception of the title of the ET 1940 series, chosen by Wittgenstein himself - were given by Smythies, and "may suggest a more determinate topic than Wittgenstein actually intended to follow in each case" (Munz, Ritter 2017: xv).

${ }^{16}$ Smythies' transcription of the lectures comes without a date (for the reasons to date them back to LT 1940 see Munz, Ritter 2017: 133-135). Considered several factors, March 4 looks like a possible date for this lecture.

${ }^{17}$ Wolf Mays, who attended Wittgenstein's lectures from early 1940 to late 1941, recalls him as using James' Principles of Psychology, but the fact is confirmed neither by Smythies' notes nor by those of Rose Rand (WCL: 252). James quoted the Treatise while discussing several topics: ideas as mental images (1890: 691-2), the treatment of personal identity in the Associationist Theory (1890: 332-334), association (1890: 561-562), and finally belief (1890: 924-5, 931).
} 
reference is unfaithful to Hume's wording; not only Hume's idea would have been better conveyed adding after "perceptions" something like 'from which they [images] derive from', but the expression vivacity and liveliness occurs in none of Hume's texts. While stating the different "degrees of force and liveliness with which [impressions and ideas] strike upon the mind" (T I.I.I, Hume 1978: 1, emphasis mine), Hume sometimes used vivacity instead of liveliness, this meaning that he considered the first noun as synonymous with the second, not with force. ${ }^{18}$ As regards the issue debated in the present essay, Hume compared only implicitly the degrees of force and liveliness of impressions and ideas in the Abstract (i.e. Hume 1938: 8); and Wittgenstein's conclusion that "if [images] only had more vivacity, they'd be perceptions" perfectly catches Hume's point, straightly expressed in the Abstract where ideas were defined precisely as "weak perceptions" (ibid.: 9).

Any direct mention of one of Hume's texts, the Abstract in particular, can then be excluded here; and it can also be excluded a quotation from Russell's or James' works, since they never used vivacity as a synonimous of force while discussing Hume's claim. Wittgenstein had however alluded to Analysis of Mind a few months before, opening his lectures for MT 1939 (WCL: 88, n.6), and a textual reason can be added for plausibly tracing back also this reference to the pages denying that "the difference between sensations and images is only of degree" (Russell 1921: 147). Discussing Stout's perspective (a "modification of Hume's" view not avoiding in his opinion its main defect, Russell 1921: 147-148), Russell quoted his reflections about the "force or liveliness" of the percept "supposed to be always absent from images" (ibid: 148, emphasis mine), where the "or" may suggest a synonymity between force and liveliness (and then vivacity) that Hume's wording excludes. ${ }^{19}$

The editors of the lectures point to analogies with two of Wittgenstein's texts, the 1936 lecture analyzed in \$4.1 and MS 162b:

\footnotetext{
${ }^{18}$ Hume sometimes substituted also force with strength, i.e. T I.I.VII (Hume 1978: 19). T I.III.V (ibid: 86) shows that for him force and vivacity were not equal in meaning: "an idea of the memory, by losing its force and vivacity [...]".

${ }^{19}$ I owe thanks to one of the anonymous reviewers for the suggestion.
} 
$44 \mathrm{r}$, dating back to the same period of the lecture here discussed (WCL: 174, n. 71).

\subsection{Easter Term 1940-Lectures On Belief}

According to Smythies' notes, Wittgenstein mentioned Hume several times in the next series of lectures, that he himself entitled On Belief (WCL: 203- 250).

Lecture 1 [14.4.1940] ${ }^{20}$

First of all, isn't it queer that Hume should have told us that belief is a feeling, which can only mean that, if anyone says, 'I believe', he is saying, 'I have this feeling', etc.? The question is: 'Why are we inclined at all to say that 'to believe' means "to feel something"?

[...]

That there are experiences characteristic of expectation doesn't mean there is any element in common to all the experiences we call characteristic of expectation. To say, 'I expect so and so' doesn't say anything at all of what I feel when I say it. - In some cases, where you have an extremely strong belief, you won't have any feeling of conviction.

You could say, in a very deep sense, that these feelings are as different as these tones of voice (correlates of the feeling). There are an infinite number of ways of uttering belief, corresponding to an enormous number of feelings going along with belief. It is very queer that Hume should have written that, because, on second thoughts, you'd see that we don't know for our lives one feeling of belief. (WCL: 204- 205)

The notion of belief had been a topic of Book I of the Treatise upon which the Appendix to Book III had extensively commented. Consequently, an editorial note (WCL 204: n. 8) couples the first

\footnotetext{
${ }^{20}$ The lectures go undated in Smythies' notes (for the reasons for locating them in ET 1940, see Munz, Ritter 2017: 134, 200-203). Since full LT run from April 15 to June 10, Wittgenstein lectured once a week on Sundays (Klagge and Nordmann 2003: 354), according to Smythies' notes the lectures were ten, and finally one of them was on Tuesday May 21 (Munz, Ritter 2017: 201), then he possibly lectured on 14/4, 21/4, 28/4, $5 / 5,12 / 5,19 / 5,21 / 5,26 / 5,2 / 6,9 / 6$.
} 
paragraph with both Treatise, I.III.V ("to believe is [...] to feel an immediate impression of the senses, or a repetition of that impression in the memory", Hume 1978: 86) and Appendix, addition to I.III.VII ("belief consists not in the nature and order of our ideas, but [...] in their feeling to the mind", Hume 1978: 629). For the current investigation, it is remarkable that the Appendix defines belief with words even more similar to those chosen by Wittgenstein - as "merely a peculiar feeling or sentiment", "nothing but a peculiar feeling", consisting "in some impression or feeling" (Hume 1978: 623-625, see also 626), excerpts that resume almost verbatim sentences of the Abstract, for instance "belief consists merely in a peculiar feeling or sentiment", and "whatever name we may give to this feeling, that constitutes belief [...]" (Hume 1938: 20-21).

The view according to which belief is a feeling was central for both Russell (1913: 136-140; 1921: 231-252) and James, who quoted the above mentioned excerpt of the Appendix (1890: 924) and was quoted in turn by Russell (1921: 252); ${ }^{21}$ this view being under Wittgenstein's attack since 1930, the section of Analysis of Mind dealing with belief looks again as the natural background for this remark. This time, however, lexical nuances suggest a more direct approach to Hume's thought; for instance, the register in which he put forward Hume's claim (also in lectures 2 and 3, see infra) has changed ("Hume [...] told us", whereas he previously said "Remember Hume's description that [...]", "Cf. Hume's remarks that $[\ldots]$ "); a direct reading is suggested also by the second mention ("It is very queer that Hume should have written that [belief is a feeling]"). Finally, notwithstanding the central place of Hume's claim in Russell's theory, the section of Analysis of Mind concerning belief does not quote him.

The editors of the lectures signal parallels amongst the sentence "that there are experiences characteristic of expectation doesn't mean there is any element in common to all the experiences we call characteristic of expectation" and Wittgenstein's remarks dating back to 1934-1936 (WCL: 205, n. 9), and also amongst the

\footnotetext{
${ }^{21}$ Mays recalls that Wittgenstein used James' Principles of Psychology specifically in the lectures on belief, but again the fact is confirmed neither in Smythies' notes nor in those of Rand (WCL: 252).
} 
sentence "there are an infinite number of ways of uttering belief, corresponding to an enormous number of feelings going along with belief' and remarks the first of which dates back to 1933/1934 (WCL 205: n. 10).

Lecture 2 [21.4.1940]

If a man like Hume explains a word like 'believe' by saying, 'It refers to a feeling', you can immediately ask why he does it when it so obviously doesn't refer to a feeling. What should make a man who has thought a lot about it say such a thing? You couldn't say, 'He didn't know what it is to believe'. He used this word every day. In the ordinary sense, he knew perfectly well what it is to believe. It must be something very queer to make a man who writes about it give a wrong explanation, say something quite wrong. What I mean is: 'Would you understand if I said, if we get clear why Hume said this, we'll get clearer about what our problem is?' What axe has a man to grind if he gives such an explanation?

[Student:] He wanted to say something about the thing, about the content of the thing. He wanted to say something about belief.

[Wittgenstein:] That would be something like the properties of the thing. Normally, if you said something about the thing, I wouldn't know whether you wanted to know the definition of the thing or the properties of it.

"Something about belief" - would this mean that when people believe so and so, it has such and such effects on them? The whole point is: why did he classify belief with feelings? Or, what comes to exactly the same thing: 'the word 'belief means a feeling'? The point is: why should a man even be tempted to give what you might call 'a false analysis' of belief?

Cf. 'Losing in a game of chess is a feeling'.

He might have said, 'It is a feeling: I can't explain it any further to you'. - This might mean that he couldn't think of a feeling, or, he might have said: 'It is the feeling that all of us have (attached) to the proposition 'I see', unless we are blind'.

The words, that we must all know it in our breast, add nothing to saying, 'It is a feeling', unless it adds that he can't give an explanation.

It seems as though it were an explanation in this way: it appears to show us where to look for it. If you want to know what a belt is, just open your jacket and you will find it. It would seem to show us a place where to find it, which of course it doesn't, unless is true of every feeling. This appendix seems to be, although not an explanation, at 
any rate a hint of an explanation. The trouble is of course, that you wouldn't know where to look." (WCL: 210-211)

The sentence "the words, that we must all know it in our breast, add nothing to saying, 'It is a feeling', unless it adds that he can't give an explanation" (emphasis mine) strongly suggests that Wittgenstein was referring to the Abstract. Not only did Hume use precisely the words used by Wittgenstein; he did it in the Abstract and only there ("tis impossible by words to describe this feeling [of belief], which every one must be conscious of in his own breast", Hume 1938: 19). Hume must have soon realized the emptiness of the expression, because he never used it again, not even in the Appendix, where he resumed almost verbatim the text of the Abstract about belief. ${ }^{22}$ The fact that he was recognized as the author of the Abstract only in the mid-Thirties excludes a quotation from Russell's or James' works.

\section{Lecture 3 [28.4.1940]}

Suppose I said, 'Asking a question is having a feeling which everyone knows in his own breast'.

Suppose the door bangs and we say, 'I believe he has come', and a child hears this. Suppose, this happens again, and then the child himself says, 'I believe he has come'. You might say this doesn't explain what the child meant, because the child might have just said it mechanically. What, I wonder, is the difference between 'repeating it mechanically' and 'actually believing he has come'? What would our criterion be for saying the child had only said it but not understood at all what it meant, or for our having just heard it, but not understood it?

You might say: 'Oh, we feel certain things'. Mightn't I say, 'How do you know you feel the right things?' How does Hume know he doesn't feel a wrong thing? (WCL: 214)

\footnotetext{
22 "Belief consists not in the nature and order of our ideas, but in the manner of their conception, and in their feeling to the mind. I confess, that 'tis impossible to explain perfectly this feeling or manner of conception. We may make use of words, that express something near it. But its true and proper name is belief, which is a term that every one sufficiently understands in common life", Appendix to Treatise, addition to I.III.VII (Hume 1978: 629).
} 
Another evidence that Wittgenstein's current discussion was directed towards the Abstract definition of belief, is that he used again the expression "a feeling which everyone knows in his own breast", and re-formulated it a few lines after ("Now we imagine lying to happen like this: In his breast, he hasn't this feeling, but he says he believes", WCL: 214). Previously in the lecture, he had already alluded to it ("To say such a thing as that to believe means to have a certain feeling which we all know, this sort of explanation is due to the fact that we want to give an explanation [...]", WCL: 212-213), and in lecture 5 he extended the supposed explicative power of Hume's description to the analysis of boredom ("You might say: 'If only he, in his own breast, knows what boredom is [...] then he also knows what it means if one says that the other person is bored, and in fact knows the whole application of "to be bored".' [...] Suppose I gave the explanation of boredom that in each of your breasts there are several things you could look at. [...]", WCL: 225-226).

\section{Lecture 8 [26.5.1940]}

My chief object was always coming back to the question of belief, personal experience, feeling. Always stating, coming back to, the quotation of Hume's. Because it is colossally characteristic.

'In your own breast' means something like 'direct your gaze inward, and then you'll find what belief is', etc. (WCL: 237)

The commas surrounding the expressions "in your own breast", possibly written down by Smythies because Wittgenstein mimed them, reinforce the hypothesis that Wittgenstein was discussing a specific passage of the Abstract. The reason he gives for his frequent "coming back to the quotation of Hume's", namely its being "colossally characteristic", shapes the perspective (and the limits) within which he indulged on a direct examination of Hume's claim - attacking the original source of Russell's and James' thoughts about belief.

Lecture 10 [9.6.1940]

When I say, first of all, 'Lewy sits on the third chair from the door', 'Lewy doesn't sit on the third chair from the door', or 'I expect Lewy will sit on the third chair from the door', well, here I am not really 
talking of the fact of Lewy sitting on a chair at all. When I expect him to, observe he doesn't do it - [there is] something more vague than actual feelings. This is what Hume meant when he said ideas were more vague than impressions. (WCL: 249)

As regards the final sentence, it is remarkable that although Hume never described ideas as more vague than impressions, in the Abstract (and only in this text) he qualified them as possibly ambiguous ("wherever any idea is ambiguous, [our author] has always recourse to the impression, which must render it clear and precise", Abstract. 10) - a sentence not resumed in the Appendix. It seems unlikely that Wittgenstein had here James' or Russell's texts in mind, because they both hold that Hume's theory left no room to vagueness of ideas (images, in their perspectives); in Analysis of Mind, for instance, Russell clearly stated that Hume's attack on general ideas did "not allow for the vagueness of images" (Russell 1921: 208; cf. also Russell 1927: 199-200). ${ }^{23}$

The editors of the lectures signal analogies amongst the paragraph to which the excerpt belongs and remarks the first of which dates back to 1933/1934 (WCL: 249, n. 64).

\section{Conclusion and Hints for Further Research}

The previous section suggests that when Wittgenstein mentioned Hume in May 1936 and March 1940 he had Russell's discussion of Humean claims in Analysis of Mind in mind, whereas the mentions in the series On Belief were subsequent to his reading (parts) of Hume's Abstract.

The evidence of this reading, the extent of which remains to be assessed, not only disconfirms the received view that Wittgenstein never read Hume, ${ }^{24}$ but adds an element to the reconstruction of

\footnotetext{
${ }^{23}$ Cf. James (1890: 246, 691) and (1892: 150).

${ }^{24}$ Karl Britton wrote that Wittgenstein told him that "he could not sit down and read Hume - he knew far too much about the subject of Hume's writings to find this anything but a torture" (Britton 1955: 1072). Hanfling, the first to investigate similarities and differences between Wittgenstein and Hume, inferred from this memory that Wittgenstein never read Hume - as "a large part of the literature which most philosophers would regard as essential to a knowledge of their subject" (Hanfling 1976: 47). Five years later his
} 
his critique of the picture of belief as a mental act or feeling. As the Lectures on Belief confirm, along the assault he moved from 1930 onwards to the traditional account of belief (that had Russell as a main target from the beginning, included James on the way and finally focussed on Moore), there was a time in which he faced Hume directly, or at least the definition of belief he had given (only) in the Abstract. ${ }^{25}$ His direct confrontation with the source of the 'traditional view' on belief was short, possibly because, as he said later to Britton, "he knew far too much about the subject of Hume's writings to find [reading him] anything but a torture" (Britton 1955: 1072).

What moved him in Spring 1940 on this source can be imagined locating his reading of the Abstract along the lines suggested by the comparison between the mentions of Hume in March and the others in April. Wittgenstein had announced an investigation on the uses of the verb 'to believe' already in 1938, in the first set of the WCL, ${ }^{26}$ but in fact he performed it only two years later, and one

conclusion seemed corroborated by M.O'C. Drury's report of his conversations with Wittgenstein: in LT 1930, while they were talking about various philosophers, Drury happened to say "I was recently at a lecture by Professor A. E. Taylor in which he said that he could never make up his mind whether Hume was a great philosopher or only a very clever man [...]”, and Wittgenstein replied: “About Hume I can't say, never having read him, but the distinction Taylor made between philosophy and cleverness is a very important one" (Drury 1981b: 121, emphasis mine; Drury 1981a: 95 has "the distinction between a philosopher and a very clever man is a real one and of great importance"). Scholars assumed then that Wittgenstein never read Hume (i.e. Kripke 1982: 63; Fogelin 2009: 22, n.6; Steiner 2014: 202), but while Drury's report tells us that Wittgenstein had not read Hume by LT 1930, Britton's words suggest that he tried to; their conversations run in 1946, so Wittgenstein could have thought of his reading of Hume's Abstract in Spring 1940. Both Britton's statement and the unworn look of the book (n.2) suggest that Wittgenstein put the pamphlet aside soon, but further research is needed to exclude a more careful reading.

${ }^{25}$ Wittgenstein objected to Hume that belief and conviction do not coincide (WCL: 205213); that "a word like 'believe' [...] obviously doesn't refer to a feeling” (WCL: 210); and that even if belief could be conceived of as a feeling "there are an infinite number of ways of uttering belief, corresponding to an enormous number of feelings going along with belief' (WCL: 205).

${ }^{26}$ See (WCL: 28-29, 40, 43). At that time, though, and until 1940, Wittgenstein (briefly) discussed the verb 'to believe' as supposedly referring to a state of mind, not a feeling cf. also the summary after Malcom's notes lecture 6 of the series on Similarity: "Wittgenstein says that we are continually misled by the grammar of 'to remember', 'to believe', 'to know', 'to think', 'to mean' and 'to understand', in such a way as to think that these verbs stand for mental states, or mental acts" (WCL: 97). 
may wonder whether his reading of Hume's pamphlet had any role in finally turning his lectures towards it. If he leafed through the Abstract after mentioning Hume in March, possibly to refresh the idea of images "lacking in the vivacity and liveliness of perceptions" (WCL: 174), he might have been captured by the description of belief as a feeling he found there - the source of Russell's and James' thoughts. A fortnight later, in fact, he focussed (part of) his last lecture for that term upon the notion of belief as a feeling (WCL: 183-186), ${ }^{27}$ and decided also to tackle the issue in depth in the incoming term - as he made clear opening the new series of lectures inviting his students to "concentrate on the feeling of belief' (WCL: 203).

Evidence of Wittgenstein's reading of the Abstract may also contribute to the reconstruction of his intellectual intercourse with Sraffa.

As it is apparent from the ET 1940 lectures, Wittgenstein took Hume's definition of belief as "a feeling which every one must be conscious of in his own breast" in deep dislike, and not implausibly criticized it with Sraffa too. Not only Sraffa, as an editor of the reprint, knew both the words of the Abstract and the context to which they belonged, but he met with Wittgenstein as long as the latter discussed Hume's (un)description of belief as a feeling with his students (\$3). It cannot even be excluded that it was Sraffa who, during their first meeting in ET, led the philosopher's attention towards the peculiar expression Hume used in the Abstract, the

\footnotetext{
${ }^{27}$ Wittgenstein also closed the lecture with words resounding those of the Abstract, cf. "When we ask such a question as 'what belief is', we there already take for granted one particular way of looking at the thing. The particular form which a philosophical question takes is suggested to us by our use of language" (WCL: 186), with "What then is [...] belie? And how does it differ from the simple conception of anything? Here is a new question unthought of by philosophers" (Hume 1938: 17), a remark Hume reformulated in the Appendix as "what the nature is of that belief, which arises from the relation of cause and effect, few have had the curiosity to ask themselves" (Hume 1978: 623). In lecture 9 of the next series, Wittgenstein used again similar words while synthetizing his position about belief: 'Take such a word as the word 'believe' and take a philosophical question, such as 'What is belief?' [...] Now, one thing is clear, that the question itself is produced by a form of words. What I mean is, if we ask, 'What is belief?', I should say, first of all, the phenomena which play a role in belief would under entirely different circumstances have been grouped together in an entirely different way, so that no word corresponding to our word 'belief', or our concept 'belief', would have expression"' (WCL: 243).
} 
meeting shortly followed Wittgenstein's first lecture, ${ }^{28}$ and supposing he informed his friend about the topic he was to lecture on, Sraffa could have recalled the addition Hume made in the Abstract to the Treatise's definition of belief as a feeling: Wittgenstein in fact quoted Hume's words four days later in his second lecture (also his 'quotation' in the fifth lecture shortly followed a meeting with Sraffa).

Finally, the chronology of the rediscovery and reprint of the Abstract could help us to reconstruct the contextual genesis of the notes the two thinkers exchanged in January-March 1934, some of them, as Brian McGuinness detected, echoed in the Brown Book which Wittgenstein dictated the following academic year. ${ }^{29}$

On the eve of Sraffa's departure for Italy in mid-December 1933, as was said (\$3), Wittgenstein told him that for the incoming term he wished not to resume their discussions on a regular schedule. Conversations were in fact resumed at the end of January (Sraffa's diary registers no meetings for a couple of months but in fact from the end of January until the end of term they met some Sundays), ${ }^{30}$ but they were so tense to induce Wittgenstein to write down his arguments in order to make them clearer (and then "worthwhile expressing them at all", LW to PS [21.2.1934]), and until the end of term he and Sraffa in between their meetings exchanged notes meant to ease the understanding of the reciprocal arguments - this is why an evidence (albeit little) of the topics they touched upon at that time had survived. ${ }^{31}$

\footnotetext{
${ }^{28}$ Wittgenstein probably started his lectures on April 14; he met Sraffa on April 17.

${ }^{29}$ McGuinness (2008: 232-233; WC: 228-229, notes) detected similarities between BBB II. 6 (1958: 143) and excerpts of both Wittgenstein's notes for Sraffa of February 21 and Sraffa's rejoinder of the $23^{\text {rd }}$, and also echo of Sraffa's notes of March 4 shortly before the mentioned passage. On the exchange, see also Kurz (2009).

${ }^{30}$ Their correspondence suggests conversations on Sunday January 28 (LW to PS 31.1.1934, and WC: 224 n) and Tuesday February 20 (Add.ms.a 427/93a, in De Iaco 2019), and that they were to meet on Sunday 25 (LW to PS 27.2.[1934]), Sunday March 4, and the next Sunday too, but in fact they met the next Friday.

${ }^{31}$ Wittgenstein sent Sraffa notes on January 31 (LW to PS 31.1.1934) and February 21 (LW to PS [21.2.1934] and Add.ms.a 427/93a). Sraffa replied with a note the draft of which was found in his Papers (Notes by PS [23.2.1934]); Wittgenstein wrote a ten pages letter (now lost) that he meant to send once properly re-written (LW to PS 27.2.[1934]). Due to his engagements, the meeting scheduled verbatim for Sunday March 4 was cancelled, but that day Sraffa wrote down other remarks (Notes by PS 4.3.1934).
} 
These notes were exchanged shortly after Sraffa's reading of Hume's Abstract ( $(2)$, so it can be worth checking whether the topics they touch upon show any affinities with some of the ideas Hume synthetized in that text. Surely, while examining the pamphlet Sraffa's interest was captured not only by its historical mystery, but by its theoretical content too. Interested in the possibility of understanding the causes/motives standing behind people's habits and behaviour in an objective way (amongst others, cf. Kurz, Salvadori 2005; Davis 2012), he must have wondered about Hume's proposals "to anatomize human nature in a regular manner, [promising] to draw no conclusions but [those] authorized by experience" and get "perfectly acquainted with the idea of a cause", by the synthesis of the Treatise "explication of our reasonings from cause and effect", and finally by the recognition that although "we are determined by custom alone to suppose the future conformable to the past" there is however "a constant conjunction of the actions of the will with their motives, so the inference from the one to the other is often as certain as any reasoning concerning bodies" (Hume 1938: 8, 11, 16, 30).

It is not implausible that Sraffa introduced in his contemporary conversations with Wittgenstein some of the issues the reading of the Abstract raised in his mind, not necessarily mentioning the source of his reflections. For instance, the example they discussed about the future possible behaviour of Austria, Italy and Germany that they furthered in their notes concerns the degree of certainty in predicting future behaviour from past experience or other kinds

Wittgenstein finally replied with the re-written note on March 11 (Add.ms.a 427/97a, in De Iaco 2019), the day in which Sraffa noted down the first meeting with him since December: the event is uncancelled, but it did not take place because Wittgenstein, having finally completed the re-join to Sraffa's notes of February 23, felt exhausted, so he forwarded it to Sraffa explaining that he preferred not to have tea with him but rather "be in the open air all the afternoon", and proposed to "have a chat and say goodbye" the next Friday - he was leaving for Vienna (LW to PS 11.3.1934). After Easter vacation they noted down again weekly meetings in their diaries, but in May they cancelled two on four of them (possibly because they quarrelled again, cf. JMK to LLK 6.5.1934, King's/PP/JMK/PP/45/190/6/149), in June fixed no meeting at all, in July only one; in fact, their conversational practice was not resumed until ET 1935. 
of data; ${ }^{32}$ and the link the Humean remarks of interest for Sraffa had with the notion of belief as "a peculiar sentiment produced by habit" 33 could match with the correspondence remarked by the editors of the WCL between some remarks Wittgenstein noted down in 1933-1934 and reflections surrounding some of his allusions to Hume in ET $1940(\$ 4) .{ }^{34}$

\section{References}

Barens, I., 2011. “'Animal Spirits' in Keynes' General Theory of Employment, Interest, and Money: Some Short and Sceptical Remarks". In: S. Neri and C. Gehrke, eds., Keynes, Sraffa, and the Criticism of Neoclassical Theory: Essays in honour of Heinz Kuræ. London: Routledge, 21-32.

Britton, K., 1955. "Portrait of a Philosopher". The Listener LIII (1372), 10711072. Reprinted in K. T. Fann, ed., Ludwig Wittgenstein. The Man and his Philosophy, New York: Dell Pub. Co., 1967, 56-61.

Davis, J.B., 2012. "The change in Sraffa's philosophical thinking". Cambridge Journal of Economics 36(6), 1341-1356.

De Iaco, M., 2019. "Wittgenstein to Sraffa: Two newly-discovered letters from February and March 1934". Nordic Wittgenstein Review 8(1-2), in this volume.

Drury, M.O'C., 1981a. "Some Notes on Conversations with Wittgenstein". In: R. Rhees, ed., Ludwig Wittgenstein Personal Recollections. Oxford: Basil Blackwell, 91-111.

Drury, M.O’C., 1981b. “Conversations with Wittgenstein”. In: R. Rhees, ed., Ludwig Wittgenstein Personal Recollections. Oxford: Basil Blackwell, 112189.

Fogelin, R.J., 2009. Taking Wittgenstein at His Word: A Textual Study. Princeton and Oxford: Princeton University Press.

\footnotetext{
${ }^{32}$ LW to PS 31.1.1934, Notes for P. Sraffa [21.2.1934], Notes by P. Sraffa [23.2.1934], Add.ms.a 427/97a.

${ }^{33}$ See, for instance, "when the cause is presented, the mind, from habit, immediately passes to the conception and belief of the usual effect"; "almost all reasoning is there reduced to experience; and the belief, which attends experience, is explained to be nothing but a peculiar sentiment, or lively conception produced by habit" (Hume 1938: 19, 24).

${ }^{34}$ I owe special thanks to Christian Gehrke, Giancarlo de Vivo, Brian McGuinness, Volker Munz, Nerio Naldi, Alois Pichler, and the anonymous reviewers, for helpful comments and suggestions.
} 
Gehrke, C., 2010. Editorial note on 'An Abstract of a Treatise of Human Nature', prepared for forthcoming edition of the Unpublished writings of Piero Sraffa.

Hanfling, O., 1976. "Hume and Wittgenstein". In: G. Vesey, ed., Impressions of Empiricism. London: Palgrave Macmillan, 47-65.

Harrod, R. F., 1951. The Life of John Maynard Keynes. London: Macmillan. Hume, D., 1938. An Abstract of a Book lately Published; Entitled a Treatise of Human Nature, \&o. Wherein the Chief Argument of that Book is farther Illustrated and Explained (London, 1740). Reprinted in Keynes, J.M. and Sraffa P., eds., An Abstract of a Treatise of Human Nature 1740. A Pamphlet Hitherto Unknown by David Hume, Reprinted with an introduction by J.M. Keynes and P. Sraffa. Cambridge, New York: Cambridge University Press, The MacMillan Company.

Hume, D., 1978. A Treatise of Human Nature. L. A. Selby-Bigge, ed., $2^{\text {nd }}$ edition with text revised and variant readings by $\mathrm{P}$. H. Nidditch, Oxford: Oxford University Press.

Hume, D., 1975. Enquiries Concerning Human Understanding and Concerning the Principles of Morals. L. A. Selby Bigge, ed., $3^{\text {rd }}$ edition with text revised and notes by P.H. Nidditch, Oxford: Oxford University Press.

James, W., 1890. The Principles of Psychology, Voll. 1, 2, reprinted in The Works of William James, Vol. XIV, Cambridge (Ma), London: Harvard University Press, 1981.

James, W., 1892. Psychology: Briefer course, reprinted in The Works of William James, Vol. XIV, Cambridge (Ma), London: Harvard University Press, 1984.

Johnson, E. and Moggridge, D., 1978. "Editorial Note". In: The Collected Writings of John Maynard Keynes, vol. 28, 373. Royal Economic Society.

Keynes, J.M.K., 1978. "Hume". In: E. Johnson and D. Moggridge, eds., The Collected Writings of John Maynard Keynes (vol. 28), 373-390. Royal Economic Society.

Keynes, J.M. and Sraffa, P., 1938. "Introduction". In: An Abstract of a Treatise of Human Nature 1740. A Pamphlet Hitherto Unknown by David Hume, Reprinted with an introduction by J.M. Keynes and P. Sraffa. Cambridge, New York: Cambridge University Press, The MacMillan Company, v-xxxii.

Klagge, J.C. and Nordmann, A., eds, 2003. Ludwig Wittgenstein: Private and Public Occasions, Totowa, NJ: Rowman and Littlefield.

Kripke, S.A., 1982. Wittgenstein On Rules and Private Language. An Elementary Exposition. Cambridge (Ma): Harvard University Press.

Kurz, H.D., 2009. "Review article 'If some people looked like elephants and others like cats, or fish ...' On the difficulties of understanding each other: the case of Wittgenstein and Sraffa". European Journal History of Economic Thought 16 (2), 361-374. 
Kurz, H.D. and Salvadori, N., 2005. "Representing the Production and Circulation of Commodities in Material Terms: On Sraffa's objectivism". Review of Political Economy 17 (3), 69-97.

McGuinness, B., 2008. "What Wittgenstein Owed to Sraffa". In: G. Chiodi and L. Ditta, eds., Sraffa or An Alternative Economics. London: Palgrave Macmillan, 227-235.

Morra, L. 2017. "Friendship and Intellectual Intercourse Between Sraffa and Wittgenstein: A Timeline". In: (ed.) Including a Symposium on New Directions in Sraffa Scholarship (Research in the History of Economic Thought and Methodology: 35, Part B), 101-129.

Munz, V.A., Ritter, B., 2017. “Editorial Introduction”. In: Wittgenstein's Whewell's Court Lectures: Cambridge, 1938-1941 From the Note by Yorick Smythies, Malden (Mass.), Oxford: Wiley Blackwell, xiv-xix.

Russell, B., 1984. Theory of Knowledge: the 1913 Manuscript. Collected Papers, Vol 7. Boston, Sydney: George Allen \& Unwin.

Russell, B., 1921. The Analysis of Mind. London: George Allen \& Unwin.

Russell, B., 1927. An Outline of Philosophy. London: George Allen \& Unwin.

Skidelsky, R., 2000. John Maynard Keynes. Vol. III Fighting for Britain 19371946. London: Macmillan.

Steiner, M., 2014. "Skeptical Arguments in Hume and Wittgenstein". In: J. Berg, ed., Naming, Necessity, and More. London: Palgrave Macmillan, 202-220.

Wittgenstein, L., 1958. The Blue and Brown Books, ed. R. Rhees, Oxford: Blackwell, 1958. (BBB)

Wittgenstein, L., 1993. "The Language of Sense Data and Private Experience”. In: J.C. Klagge and A. Nordmann, eds., Ludwig Wittgenstein. Philosophical Occasions 1912-1951. Indianapolis \& Cambridge: Hackett, 289-367. (RSD)

Wittgenstein, L., 2008. Wittgenstein in Cambridge: letters and documents 1911-

1951. Edited by Brian McGuinness. Malden (Mass.): Blackwell. (WC)

Wittgenstein, L., 2017. Wittgenstein's Whewell's Court Lectures Cambridge 19381941 From the Notes by Yorick Smythies, edited, introduced and annotated by Volker A. Munz and Bernhard Ritter. Malden (Mass.), Oxford: Wiley Blackwell. (WCL)

\section{Biographical Note}

Lucia Morra lectures Logic and Philosophy of Science at the School of Medicine of the University of Turin, Italy. The intellectual intercourse between Wittgenstein and Sraffa is currently amongst her main interests of research. 